combined into the single theorem that the greater side and the greater angle are opposite each other?

SIMON NEWCOMB

\section{THE SCIENCE OF STATESMANSHIP}

DOLITICAL science and politics are two very different 1 things; some progress has been made in methodising the facts and inductions of political economy, but politics is still little more than a chaos of party prejudices and personal invective. Yet there is surely no reason why political action, the conduct of the State, should not be guided by scientific method quite as much as the conduct of a scientific exploring expedition such as that which has so recently sailed over the North-East Passage. Prof. Nordenskjöld's feat is one of the finest instances of scientific prediction based on ascertained data that we know of, and we would recommend it to Sir William Harcourt's consideration when he contemplates taking part in another political "agitation." Sir William has succeeded in getting such a firm grasp of the real nature of scientific method, and he applied it so wittily and so well in his recent Birmingham address that we would advise him to follow out this line in real earnest. So thoroughly does he seem to understand the method of scientific research and scientific prediction, and so ably, although only in sport and to banter his opponents, did he expound it, that we think science has lost in him a successful worker. To this loss we could resign ourselves if Sir William would set himself to rescue politics from its present degraded position as a mere theatre for party strife, and to elevate it into something like a science of national life and progress. He must have taken considerable pains to obtain his knowledge of the method and uses of the Nautical Almanac; his natural mistake as to its editorship we can overlook. As to the truth of his application of the method of the almanac to the construction of a Conservative Almanac, "after a careful induction from the conduct of Tory government," we have nothing to do here; its ingenuity is amusing. With the following remarks, however, men of all parties cannot but agree :-

"Prediction in politics is not a matter of choice, but of necessity. If public men are not fatalists like the statesmen of our darling Islam, they are bound to foresee and foretell the consequences of their action by which the fortunes of the country are determined. As the predictions prove true or false so will they be judged, for political prophecy, founded upon correct observation and just inference, is nothing else but the science of statesmanship itself."

Here Sir William has struck a vein which might be worked out to the elevation of politics, and with real good to the country. It is, we believe, regarded as an incontrovertible axiom in British politics, that government by party is the surest method of securing the most efficient conduct of public affairs. This point we shall not discuss; but we venture to think that if our political leaders were to give their serious attention to the method indicated above, party differences would be fewer than they are, and party strife less bitter, while the objects supposed to be aimed at by all constitutional governments would be much more effectually and rapidly accomplished.

At present, to judge from the public utterances of our members of parliament and by the results achieved by which ever party may be in power, party government consists mainly in strenuous efforts made by each party either to keep or to obtain place and power; this is accomplished by means of what are called "agitations," the great object of which seems to be to agitate the people into the belief that the agitators are angels from heaven who have the good of the nation disinterestedly at heart, while their opponents are quite the reverse, the only object of the latter being, it is declared, to send the nation to the custody of the person whose emissaries they are.

There are one or two eminent men of science in parliament, but no one of either party ever seems to think of looking at any measure or any line of conduct apart from party bias, and solely as a matter for scientific consideration. It seems enough to damn a measure at once in the eyes of one party, that it originates with their opponents. This is both unscientific and irrational, and can never lead to the best results. The same laws that influence the development of the individual influence the real progress of the nation, and it is only by honest investigation on strictly scientific principles that these laws can be discovered. It is thus that they have been discovered and expounded by Mr. Darwin and his followers in the case of individual organisms, and we would commend to Sir William Harcourt the study of Mr. Darwin's works, if he really desires to arrive at the true principles of scientific statesmanship. One of the great charms of Mr. Darwin's works to the man of science is their perfect candour and fairness. Not only does he adduce all the arguments he can muster in favour of any position or hypotheses he may be considering, but with equal fulness and candour does he treat all, according to his lights, that might be adduced against it, balancing the one series of arguments against another, not in the style of a special pleader, but after the manner of a judge whose sole aim is to discover the truth. Here is a specimen of the method followed by Mr. Darwin, showing his ingenuity in imagining objections to his own theories and thus putting arguments into the mouths of his opponents. We quote from the "Origin of Species" (I860, p. 462):-

"As on the theory of natural selection an interminable number of intermediate forms must have existed, linking together all the species in each group by gradations as fine as our present varieties, it may be asked, Why do we not see these linking forms all around us? Why are not all organic beings blended together in an inextricable chaos? With respect to existing forms, we should remember that we have no right to expect (excepting in rare cases) to discover directly connecting links between them, but only between each and some extinct and supplanted form. Even on a wide area, which has during a long period remained continuous, and of which the climate and other conditions of life change insensibly in going from a district occupied by one species into another district occupied by a closely allied species, we have no just right to expect often to find intermediate varietics in the intermediate zone. For we have reason to believe that only a few species are undergoing change at any one period; and all changes are slowly effected. I have also shown that the intermediate varieties which will at first probably exist in the intermediate zones will be liable ta be supplanted by the allied forms on either hand; and the latter, from existing in greater numbers, will generally be modified and improved at a quicker rate than the intermediate variecies, which exist in lesser numbers; 
so that the intermediate varieties will, in the long run, be supplanted and exterminated.

"On this doctrine of the extermination of an infinitude of connecting links, between the living and extinct inhabitants of the world, and at each successive period between the extinct and still older species, why is not every geological formation charged with such links? Why does not every collection of fossil remains afford plain evidence of the gradation and mutation of the forms of life? We meet with no such evidence, and this is the most obvious and forcible of the many objections which may be urged against my theory. Why, again, do whole groups of allied species appear, though certainly they often falsely appear, to have come in suddenly on the several geological stages? Why do we not find great piles of strata beneath the Silurian system, stored with the remains of the progenitors of the Silurian groups of fossils? For certainly on my theory such strata must somewhere have been deposited at these ancient and utterly unknown epoch in the world's history."

Did we urge Mr. Darwin's method upon the members of our two great political parties, we fear we should only be laughed to scorn. And yet is not such an attitude in any body of men, most of all in those men whose duty it is to discover what is best for the welfare of the State, well calculated to inspire honest and thoughtful men with imclanclioly? Fancy Mr. Gladstone bringing before an audience during one of his great "agitation" tours, not only all that can be said against any of Lord Beaconsfield's foreign coups, but, on the other side, all that could be said in favour of them, and then striking a judicial balance. And would not Lord Beaconsfield be considered as indulging in a huge joke, if, after a Mansion House dinner, he should proceed to treat the conduct of his great opponent after a similar fair and judicial fishion. And yet this would be the true scientific method of arriving at the truth in public affairs, just as it is in the investigations with which physical and natural science deals. And it is really because our parliamentary agitators despise their audiences that they treat them to only one side of a question; and if these audiences were as intelligent as they ought to be, they would not listen to any public agitator who treated them so one-sidedly. By and by let us hope that the nation will be so far advanced that politicians will give and the public will insist on being told all that can be said both for and against any measure. "Agitation," however, is not the best atmosphere in which to carry on scientific work; quite the opposite. And we should advise those of our public men who are really desirous to discover the science of statesmanship, and to guide their public conduct by its principles, to leave the method of agitation alone for a period, and take to calm but rigid scientific research in their own department, and we are sure the results will surprise even themselves. Scientific method is peculiar to no section of phenomena; it is rapidly embracing many departments of research that at one time were thought to be beyond the pale of science; and we venture to think that in no department could it be applied with greater success than in that department which hitherto has been almost entirely under the sway of prejudice and blind party spirit. Sir William Harcourt has clearly shown what can be done in sport; let him and others now try as earnestly whether even greater success would not attend scientific political prediction in earnest.
In the case of individuals, if we know their constitutions and their circumstances, we can to some extent guide their development and influence its direction; we can to some extent help them in the struggle for existence, and enable them to comply with the law of the survival of the fittest. Whether or not these two laws would justify the recent conduct of foreign affairs by the present Government, it is not for us to say. That conduct we know is justified by many on these grounds; at all events, we believe that if scientific statesmanship, and not mere party prejudice, were the guiding principle in the conduct of public affairs, this nation would be more fitted than ever to survive and play the leading part in the affairs of the world.

Scientific retrospection is quite as important as scientific prediction; we must recognise all the causes and their interactions or we may go wrong ; but $\mathrm{Mr}$. Bright in his recent sketch of the progress of the country during the past fifty years, altogether ignored what we believe the most important factor-the results of scientific research. Even granting the value of all the political measures to which he referred, where would the country have been at the present day had it not been for the results obtained by the quiet workers in science? Some time ago he gave a great Free Trade speech, in which he dwelt upon the immense benefits which have accrued to the country from the line of policy indicated by that expression. He went on sketching the progress of free trade, and the concomitant progress of the country, as if no other cause could possibly have been at work, and as if such powers as science, railroads, penny posts, improved machinery, increased population, and the likegave no greater impulse to the development of the nation than an annotated edition of an obscure classic by a still more obscure Oxford don. It is not for us to pronounce on the merits or demerits of free trade or protection, but we venture to think that all that can be said in favour of either the one or the other is small when compared with the services rendered to the country by science during the past fifty years. What about railways, and telegraphs, and the great results of engineering skill, and the application of science to manufactures and agriculture, improvements in navigation, the invaluable practical discoveries of chemistry, and a thousand and one other fruits of scientific research?

Of these the political partisan takes no account ; his function, as compared with that of the true worker in science, seems to us pretty much like that of the organ-blower as compared with the organist. We have said that there are one or two really able men of science in parliament; but they are only one or two. Probably in no parliament in Europe is science so sparsely represented, and yet we do not advise our real scientific workers to seek admission into an arena that we fear would be little congenial to them. But is it not high time that all our members of parliament should be really well-educated men, know something about the principles and results of a department which has done so much for the nation and on which its real welfare and progress so largely depends? Sir William Harcourt has shown that there is no reason why this should not be done, and we trust that not only will he follow out the course he has so well begun, and do this not merely for a gibe, but that his example will 
stimulate other well-meaning members of parliament to do what they can to qualify themselves to conduct the legislation of the country on broader, more enlightened, and more scientific principles than have ever hitherto been brought into play. Meantime those who have the true welfare of our country at heart will use every means to get education in science introduced into all our schools and colleges without distinction, so that in future years rulers and people will be guided in their public conduct not by party prejudices but by the principles of scientific statesmanship.

\section{NICHOLSON'S PALAEONTOLOGY}

A Manual of Palaontology, for the Use of Students. With a General Introduction on the Principles of Palcontology. By H. Alleyne Nicholson, M.D., \&c., Professor of Natural History in the University of St. Andrew's. Second Edition. (W. Blackwood and Sons, I879.)

$\mathrm{T} T$ is a great pity that there should be any demand for 1 a Student's Manual of Palæontology. The separation of the study of extinct forms of life from that of recent animals, which is implied in the term Palæontology, and which is unfortunately largely maintained in practical science, is much to be deplored. In nearly all great museums, as in the British Museum, the fossil series of animal remains are preserved and displayed in different parts of the museum from that in which the recent ones repose and are studied and taken care of by a separate staff of officials. The extinct corals, for example, are in the hands of one set of naturalists and the recent corals in the hands of another, the most closely allied or even identical species are widely separated from one another, and considerable labour and trouble are caused to any observer who wishes to bring them together for comparison. There are necessary gaps enough in the various zoological series from the imperfection of the geological record; in museum collections they should be rendered as small as possible.

Prof. Nicholson's book cannot take the place of such a work as Quenstedt's "Petrefactenkunde," which has a proper standpoint as being required by the geologist as a means of identifying fossils. The present work may be described as an attempt to teach students as much as possible about those forms of life which happen to be extinct, by means of the aid of as little knowledge of living forms as possible. The author writes in the introduction: "Palæontology may be considered as the zoology and botany of the past. Regarding it from this, the only true point of view, some knowledge of zoology and botany is essential to the prosecution of the study of palæontology, and such details of these sciences as may be deemed requisite will be introduced in the proper place." Some knowledge of zoology and botany is indeed required to make a man a successful palæontologist; the real fact is, that it is only the most skilful and deeply-versed zoologists and botanists who are capable of dealing with the problems of palæontology with any valuable result. Only those most intimately acquainted with living forms are qualified to deal with the fragmentary remains of extinct animals and plants.
It would be well, indeed, if the term palæontology were abolished, and with it any pretensions of investigators to treat fossils from a separate standpoint. Botanists are full of complaints of the confusions introduced into their science by the operations of certain palæo-botanists, to use the present author's term, who manufacture genera and species wholesale from impressions of single leaves or even fragments of leaves, and there are plenty of confusions equally detrimental in the nomenclature of extinct animals. It is most illogical to separate the members of the animal and plant series for purposes of study into two groups: that containing those forms which exist at the present epoch, and that embracing those which have lived and mostly become extinct during the vast antecedent period of which record remains. The separation is a purely artificial one, productive of no good, illustrating no general scientific law, coinciding with no natural division of the biological series: and is, further, one especially likely to produce misleading impressions in the minds of students.

Throughout the book the author recurs again and again to the distinction of palæontology as a science from zoology and botany. He writes of palæontology as based on the kindred sciences of zoology and botany. "No satisfactory acquaintance with the former can be arrived at without the previous acquisition of some knowletge of the latter." "A few points of these sciences may be noticed as having special bearing on the study of palaontology." Further on, in an account of Prof. Huxley's now abandoned group, the Annuloida, which is retained in the present work, it is mentioned that "The subkingdom was proposed by Huxley as a provisional arrangement to include the two groups of the Echinodermata and Scolecida, and the following extraordinary statement follows: Whether this arrangement be witimatsly retained or not matters not at all to the palcontologist, as no member of the Scolecida is known in the fossil condition. Could any teaching be more pernicious to a student?

After several very good introductory chapters on general geological subjects, Chapter VI. treats of the divisions of the animal kingdom and succession of organic types. The author, after treating of the development theory, concludes by patting the Darwinian theory complacently on the back "as an invaluable, indeed an indispensable, working hypothesis," but most unfortunately for the value of his book, he does not make use of the theory as a working one, but considers it "preferable to enter upon the study of the actual facts unfettered by præconceptions and unpledged to theories." He accordingly treats of the classification of the animal kingdom in most antiquated style. All animals may be classed under five or six "morphological types," and "no comparison is possible between an animal belonging to one sub-kingdom and one belongirng to another, since their distinguishing charaeters are the results of the modification of two essentially different ground plans."

"We must abandon the idea that it is possible to establish a linear classification of the animal kingdom." But why suggest any such erroneous idea as this latter to the student at all? If only the working hypothesis had been adopted, the real meaning of modern scientific 